\author{
DEPARTMENT OF THE INTERIOR \\ UNITED STATES GEOLOGICAL SURVEY
}

\title{
AEROMAGNETIC MAP OF THE RANGELEY QUADRANGLE AND PART OF THE KENNEBAGO LAKE QUADRANGLE FRANKLIN AND OXFORD COUNTIES, MAINE By
}

G. R. Boynton and F. P. Gilbert

GEOPHYSICAL INVESTIGATIONS

MAP GP-480

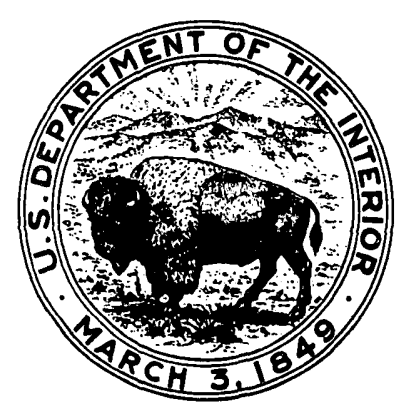

